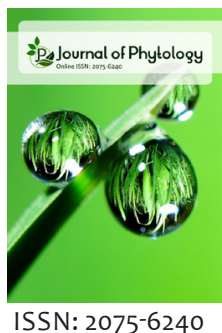

ISSN: $2075-6240$

\title{
Effect of plant growth regulators on growth and yield of chili (Capsicum annuum L.)
}

\author{
Anolisa, Md. Al-Imran, Riyad Hossen, A.T.M. Rafiqul Islam, Subroto K. Das* \\ Department of Botany, University of Barishal, Barishal-8200, Bangladesh
}

\begin{abstract}
Chili (Capsicum annuum L.) is an important food additive with high medicinal value. To investigate the effect of plant growth regulators on chili, seedlings of chili were collected from the local market and grown in the experimental field of the University of Barishal, Bangladesh. Foliar spray of different degrees of plant growth regulators, Gibberellin (50 mg/l, $100 \mathrm{mg} / \mathrm{l}, 250 \mathrm{mg} / \mathrm{l}, 350 \mathrm{mg} / \mathrm{G} \mathrm{GA}$ ) and Cytokinin $(50 \mathrm{mg} / \mathrm{l}, 100 \mathrm{mg} / \mathrm{l}, 250 \mathrm{mg} / 1,350 \mathrm{mg} / \mathrm{Kn}$ ) were applied from 15 days of germination. Data on different growth and yield parameters were collected and analyzed statistically. The result reveals that there is a significant difference in growth and yield related traits in chili due to the application of plant growth regulators. An optimum level of PGRs application shows better performance compare with control. Plant height particularly influenced by $\mathrm{GA}_{3}$ whereas other attributes like the number of leaves, branches, flowers and fruits are greatly influenced by the application of kinetin.
\end{abstract}

*Corresponding Author:

Subroto K. Das

E-mail:mrsubroto@yahoo.com

KEYWORDS: Chili, Plant growth regulator, Gibberellin, Kinetin, Growth parameters

\section{INTRODUCTION}

Chili (Capsicum annuum L.) is a member of the family Solanaceae, cultivated all year round for variable purposes $[1,2]$. This crop is famous for its pleasant aromatic flavor, pungency and high colouring substance. The placenta of chili fruits contains phenolic acid compound "capsaicin" which is responsible for the pungency in chili. The pigment "capsanthin" gives the bright red colour of chili at the ripening stage [3]. Chili fruit is mainly used as a food additive. In addition, it is also used as traditional medicine, like for the treatment of cough, toothache, sore throat, parasitic infection, wound healing, and also utilized as an antiseptic, antioxidant, and immunemodulator etc. $[4,5,6]$.

The inherent genetic yield potential of the cultivars along with several environmental factors and cultivation practices govern the production of chili. Flower and fruit drop caused by physiological and hormonal imbalance in the plants particularly under unfavorable environments, such as extremes of temperature i.e. too low or high temperatures is one of the major problem in chili production [7, 8, 9]. Over $60 \%$ of the flowers produced in a chili plant are shed. So, yield can be increased by decreasing flower drop. This problem can be solved by selection of breeding lines which retain large proportion of flowers or physiological manipulations by spraying of plant growth regulators (PGRs) which reduces the flower drop [10].

Plant growth regulator is an organic compound, either natural or synthetic, that modifies or controls one or more specific physiological processes within a plant. The plant growth regulators are known to enhance the source sink relationship and stimulate the translocation of photo assimilates thereby helping in better retention of flowers and fruits. Besides this, the growth regulators have the ability to cause accelerated growth in plants. Application of PGR in small amounts modifies the growth of plants usually by stimulating or inhibiting part of the natural growth regulatory system. PGRs are known to enhance the source sink relationship and stimulate the translocation of photo assimilates thereby helping better fruit set.

Among the sixty plant growth regulators which are now commercially available several have reached considerable importance in crop production [10]. Among them gibberellin and cytokinin are very important to stimulate vegetative and reproductive growth of plant. $\mathrm{GA}_{3}$, the most common gibberellins, regulate various developmental processes, including stem elongation, germination, dormancy, flowering and fruit development. Cytokinins promote cell division or cytokines is in plant roots and shoots. They are involved primarily in cell growth and differentiation, but also affect apical dominance, 
axillary bud growth and leaf senescence. Kinetin is a type of cytokinin that promotes cell division.

The average yield of chili in Bangladesh is very low compared to other leading chili growing countries in the world due to improper cultivation management practices. Improvement of existing spice crops through proper cultural management practices need urgent attention to meet increasing demand of edible spices for the fast growing population of Bangladesh.

Therefore, attempt to increase per unit production is necessary. That is why, special attention should be made for increasing the yield per unit area by adopting improved technologies and management practices. To increase the chili production, we need to adapt improve production technology and better agronomic practices and use high yielding adapted varieties.

There are scopes for making breakthrough for improving yield through changes of hormonal behaviors. In this connection, use of plant growth regulators (PGRs) might be a useful alternative to increase crop production. The present study was conducted to select the suitable dose of exact PGR that control the growth and finally increase the chili production in Bangladesh.

\section{MATERIALS AND METHODS}

The present study was undertaken at the experimental field of Department of Botany, University of Barishal to study the effect of various growth regulators on growth responses of chili. The soil of the experimental pot will be thoroughly mixed with recommended doses of urea, Triple Super Phosphate (TSP), Muriate of Potash (MP), gypsum and cow dung for the cultivation of chili in Bangladesh. Locally grown chili plantlets were used as plant material in the present experiment. The experiment was laid out in randomized block design with three replication and five treatments. Intercultural operations like irrigation, weeding, mulching and pest control were followed as and when necessary for normal growth and developments of chili plants.

Foliar application of $\mathrm{GA}_{3}(50 \mathrm{mg} / 1,100 \mathrm{mg} / \mathrm{l}, 250 \mathrm{mg} / \mathrm{l}, 350 \mathrm{mg} / \mathrm{l})$ and Kinetin ( $50 \mathrm{mg} / 1,100 \mathrm{mg} / \mathrm{l}, 250 \mathrm{mg} / 1,350 \mathrm{mg} /$ ) were applied at 15 days after transplantation and repeat it twice a week up to harvest stage. The spray was done by hand sprayer at morning.

Height of randomly selected plants was measured by scale from ground level to the tip of the main stem of plant at 15,30 and 90 DAT. The number of branches arising on the main stem in the five randomly selected and tagged plants was recorded at 30, 60 and 90 DAT. The mean number of branches plant-1 was workout and expressed in number. The number of leaves in the five randomly selected and tagged plants was recorded at 15, 30 and 90 DAT. The number of leaves per plant was worked out and expressed in number. The number of flower and seed was recorded at the same pattern and expressed in number.

The collected data were analyzed statistically and the mean difference was adjudged by Duncan's Multiple Range Test (DMRT).

\section{RESULT AND DISCUSSION}

Findings of the study of effect of plant growth regulators on growth and yield of chili are as follows-

\section{Plant Height}

The effect of varying concentration of plant growth regulators on plant height has been presented in Table 1. Results show that there is a significant difference in plant height by the different concentration of PGRs ( $\mathrm{GA}_{3}$ and $\mathrm{Kn}$ ). In general there is an increase in plant height with the age of seedlings. At 15 DAT the tallest plant found in $\mathrm{T}_{2}\left(100 \mathrm{mg} / \mathrm{GA}_{3}\right)$. At 30 DAT and 90 DAT tallest plant was observed in $\mathrm{T}_{4}\left(350 \mathrm{mg} / \mathrm{GA}_{3}\right.$ ). Overall the highest plant height found in $\mathrm{T}_{4}\left(350 \mathrm{mg} / \mathrm{GA}_{3}\right.$ ) i.e $47.3 \mathrm{~cm}$ per plant followed by $\mathrm{T}_{3}\left(250 \mathrm{mg} / \mathrm{GA}_{3}\right)$ i.e. 39.1 , and the lowest plant height found in $\mathrm{T}_{0}$ (Control) where mean plant height was $29.6 \mathrm{~cm}$ per plant. So, a significant increase in plant height is observed by the application of PGR particularly for $\mathrm{GA}_{3}$, Which resemble the observation of Tamilselvi and Vijayaraghavan (2014) [10], Chaudhary et. al. (2006) [11] and Shankhwar et. al. (2017) [12] in chili, Ghait et. al. (2018) [13] in Dendranthema grandiflorium, Gupta et. al. (2015) [14] in China aster (Callistephus chinensis L. Nees) and Henschke et. al. (2015) [15] in Helleborus orientalis 'Red Hybrids' and Ibrahim et. al. (2010) [16] on croton plants.

The increase in height of $\mathrm{GA}_{3}$ treated plant might be due to rapid elongation, increased cell division and cell enlargement, which would have increased inter nodal distance.

\section{Number of Leaf}

Table 2 represents the effect of PGRs on number of leaf of chili plants used in the present investigation. From table- 2 it is observed that there is a significant difference in leaf number with the different degrees of $\mathrm{GA}_{3}$ and $\mathrm{Kn}$. At 30 DAT highest number of leaf found in $\mathrm{T}_{2}\left(100 \mathrm{mg} / \mathrm{GA}_{3}\right)$ whereas highest number of leaf found in $\mathrm{T}_{6}(100 \mathrm{mg} / \mathrm{Kn})$ at 15 DAT and 90 DAT of plant age. Over all the highest number of leaf found in $\mathrm{T}_{6}(100 \mathrm{mg} / \mathrm{Kn})$ i.e 57.1 followed by $\mathrm{T}_{4}\left(350 \mathrm{mg} / \mathrm{GA}_{3}\right)$ i.e 42.9 and $\mathrm{T}_{2}\left(100 \mathrm{mg} / \mathrm{GA}_{3}\right)$ i.e

Table 1: Effect of different plant growth regulators on plant height $(\mathrm{cm})$ of Chili

\begin{tabular}{lcccc}
\hline Treatments & \multicolumn{4}{c}{ Plant height (cm) } \\
\cline { 2 - 5 } & 15 DAT & 30 DAT & 90 DAT & Mean \\
\hline $\mathrm{T}_{0}($ Control) & $16.8 \pm 3.1$ & $31.0 \pm 1.2$ & $41.8 \pm 5.9$ & 29.6 \\
$\left.\mathrm{~T}_{1}(50 \mathrm{mg} / \mathrm{l} \mathrm{GA})_{3}\right)$ & $16.9 \pm 0.7$ & $36.8 \pm 5.9$ & $55.8 \pm 7.7$ & 36.5 \\
$\mathrm{~T}_{2}\left(100 \mathrm{mg} / \mathrm{l} \mathrm{GA}{ }_{3}\right)$ & $18.8 \pm 1.7$ & $35.8 \pm 4.3$ & $53.4 \pm 3.1$ & 36.0 \\
$\mathrm{~T}_{3}\left(250 \mathrm{mg} / \mathrm{l} \mathrm{GA}{ }_{3}\right)$ & $16.1 \pm 0.9$ & $43.0 \pm 3.6$ & $58.2 \pm 7.2$ & 39.1 \\
$\mathrm{~T}_{4}\left(350 \mathrm{mg} / \mathrm{l} \mathrm{GA}{ }_{3}\right)$ & $16.9 \pm 1.9$ & $53.4 \pm 2.4$ & $71.6 \pm 7.2$ & 47.3 \\
$\mathrm{~T}_{5}(50 \mathrm{mg} / \mathrm{l} \mathrm{Kn})$ & $16.9 \pm 2.4$ & $33.4 \pm 5.8$ & $44.6 \pm 5.8$ & 31.6 \\
$\mathrm{~T}_{6}(100 \mathrm{mg} / \mathrm{l} \mathrm{Kn})$ & $18.3 \pm 2.5$ & $32.8 \pm 7.5$ & $42.6 \pm 5.3$ & 31.2 \\
$\mathrm{~T}_{7}(250 \mathrm{mg} / \mathrm{l} \mathrm{Kn})$ & $14.1 \pm 1.9$ & $26.8 \pm 4.3$ & $40.6 \pm 2.4$ & 27.2 \\
$\mathrm{~T}_{8}(350 \mathrm{mg} / \mathrm{l} \mathrm{Kn})$ & $17.2 \pm 3.9$ & $37.8 \pm 4.2$ & $39.8 \pm 2.9$ & 31.6 \\
$\mathrm{Mean}$ & 16.89 & 36.76 & 49.82 & 34.46 \\
CV $(\%)$ & 7.87 & 21.01 & 21.55 & \\
$\mathrm{SEM}$ & 0.44 & 2.57 & 3.58 & \\
CD at $5 \%$ & 1.01 & 5.93 & 8.26 & \\
\hline
\end{tabular}


41.1 whereas lowest number found in $\mathrm{T}_{7}(250 \mathrm{mg} / \mathrm{Kn})$ i.e 35.9 . This observation supported by the findings of Seema et al.(2011) [17] in Raphanus sativus and Ghait et. al. (2018) [13] in Dendranthema grandiflorium. According to this it may be assumed that optimum level of kinetin decreases the peroxidase activity which delayed the leaf senescence. Positive role of $\mathrm{Kn}$ in reducing peroxidase activity and delay senescence was noticed earlier in Cajanus cajan by Mukherjee and Rao in 2007 [18].

\section{Number of Branches}

A significant difference found in number of branches with the application of PGRs, which has been shown in Table 3. After 30 days highest number of branch (7.75) was found in $\mathrm{T}_{2}$ (100 mg/l GA $\mathrm{G}_{3}$ ) whereas maximum number of branches 12.5 and 18.5 was found in $\mathrm{T}_{6}(100 \mathrm{mg} / \mathrm{l} \mathrm{Kn})$ at 60 and 90 DAT respectively. In the mean, the highest number (12.75) was found in $\mathrm{T}_{6}(100 \mathrm{mg} / \mathrm{Kn})$ followed by 11.5 in $\mathrm{T}_{2}(100 \mathrm{mg} / \mathrm{l}$ $\left.\mathrm{GA}_{3}\right)$ and the lowest number found $7.42 \mathrm{in} \mathrm{T}_{4}\left(350 \mathrm{mg} / \mathrm{l} \mathrm{GA}_{3}\right)$. The result goes no line with that observed by Ghait et. al. (2018) [13] on Dendranthema grandiflorium and Mohamed in 2017 [19] on aster plant (Symphyotri chumnovi-belgii L.) cv. Purple Monarch. Possible causes of this type of findings can be explained by the theory of Wickson and Thimann (1958) [20]

Table 2: Effect of different plant growth regulators on leaf number of Chili

\begin{tabular}{lcccc}
\hline Treatment & \multicolumn{4}{c}{ No. of leaf } \\
\cline { 2 - 5 } & 15 DAT & 30 DAT & 90 DAT & Mean \\
\hline $\mathrm{T}_{0}($ Control $)$ & $14.50 \pm 3.3$ & $48.0 \pm 8.0$ & $51.75 \pm 7.9$ & 38.08 \\
$\mathrm{~T}_{1}\left(50 \mathrm{mg} / \mathrm{l} \mathrm{GA}{ }_{3}\right)$ & $15.25 \pm 4.6$ & $57.75 \pm 6.1$ & $50.25 \pm 2.7$ & 41.08 \\
$\left.\mathrm{~T}_{2}(100 \mathrm{mg} / \mathrm{l} \mathrm{GA})_{3}\right)$ & $15.75 \pm 5.9$ & $74.4 \pm 9.5$ & $78.25 \pm 7.5$ & 41.1 \\
$\mathrm{~T}_{3}\left(250 \mathrm{mg} / \mathrm{l} \mathrm{GA}{ }_{3}\right)$ & $14.50 \pm 2.8$ & $48.2 \pm 5.2$ & $49.0 \pm 5.7$ & 37.23 \\
$\mathrm{~T}_{4}\left(350 \mathrm{mg} / \mathrm{l} \mathrm{GA}{ }_{3}\right)$ & $14.00 \pm 1.8$ & $50.2 \pm 11.5$ & $64.5 \pm 4.0$ & 42.9 \\
$\mathrm{~T}_{5}(50 \mathrm{mg} / \mathrm{l} \mathrm{Kn})$ & $14.00 \pm 0.8$ & $49.75 \pm 7.9$ & $46.5 \pm 4.1$ & 36.75 \\
$\mathrm{~T}_{6}(100 \mathrm{mg} / \mathrm{l} \mathrm{Kn})$ & $19.50 \pm 5.6$ & $70.25 \pm 12.8$ & $81.5 \pm 7.4$ & 57.1 \\
$\mathrm{~T}_{7}(250 \mathrm{mg} / \mathrm{l} \mathrm{Kn})$ & $14.50 \pm 2.0$ & $46.5 \pm 9.8$ & $46.75 \pm 3.5$ & 35.9 \\
$\mathrm{~T}_{8}(350 \mathrm{mg} / \mathrm{l} \mathrm{Kn})$ & $15.00 \pm 6.8$ & $52.75 \pm 5.1$ & $50.75 \pm 7.5$ & 39.5 \\
Mean & 15.20 & 55.31 & 57.69 & 42.7 \\
CV $(\%)$ & 11.18 & 18.51 & 23.7 & \\
$\mathrm{SEM}$ & 0.567 & 3.41 & 4.56 & \\
CD at $5 \%$ & 1.30 & 7.86 & 10.51 & \\
\hline
\end{tabular}

Table 3: Effect of different plant growth regulators on number of branches of Chili

\begin{tabular}{lcccc}
\hline Treatment & \multicolumn{4}{c}{ No. of branches } \\
\cline { 2 - 5 } & 30 DAT & 60 DAT & 90 DAT & Mean \\
\hline $\mathrm{T}_{0}($ Control) & $5.50 \pm 2.0$ & $8.50 \pm 1.4$ & $10.5 \pm 0.5$ & 8.17 \\
$\mathrm{~T}_{1}\left(50 \mathrm{mg} / \mathrm{l} \mathrm{GA}{ }_{3}\right)$ & $5.25 \pm 0.4$ & $6.25 \pm 0.8$ & $14.75 \pm 0.8$ & 8.75 \\
$\mathrm{~T}_{2}\left(100 \mathrm{mg} / \mathrm{GA}_{3}\right)$ & $7.75 \pm 1.9$ & $9.50 \pm 0.7$ & $17.25 \pm 1.8$ & 11.5 \\
$\mathrm{~T}_{3}\left(250 \mathrm{mg} / \mathrm{l} \mathrm{GA}{ }_{3}\right)$ & $7.25 \pm 0.8$ & $9.0 \pm 1.6$ & $15.0 \pm 1.8$ & 10.41 \\
$\mathrm{~T}_{4}\left(350 \mathrm{mg} / \mathrm{l} \mathrm{GA}{ }_{3}\right)$ & $6.75 \pm 1.2$ & $7.0 \pm 1.3$ & $8.5 \pm 0.5$ & 7.42 \\
$\mathrm{~T}_{5}(50 \mathrm{mg} / \mathrm{l} \mathrm{Kn})$ & $6.00 \pm 2.1$ & $8.50 \pm 1.8$ & $15.75 \pm 0.4$ & 10.08 \\
$\mathrm{~T}_{6}(100 \mathrm{mg} / \mathrm{l} \mathrm{Kn})$ & $7.00 \pm 2.0$ & $12.5 \pm 2.1$ & $18.75 \pm 1.0$ & 12.75 \\
$\mathrm{~T}_{7}(250 \mathrm{mg} / \mathrm{l} \mathrm{Kn})$ & $6.75 \pm 2.3$ & $10.0 \pm 1.3$ & $14.0 \pm 4.3$ & 10.25 \\
$\mathrm{~T}_{8}(350 \mathrm{mg} / \mathrm{l} \mathrm{Kn})$ & $7.00 \pm 0.7$ & $9.5 \pm 1.8$ & $14.0 \pm 4.7$ & 10.17 \\
$\mathrm{Mean}$ & 6.58 & 8.97 & 14.28 & 9.94 \\
CV $(\%)$ & 12.59 & 20.02 & 22.09 & \\
$\mathrm{SEM}$ & 0.28 & 0.59 & 1.05 & \\
CD at 5\% & 0.65 & 1.36 & 2.42 & \\
\hline
\end{tabular}

where they drew attention to the fact that under the influence of kinetin many buds form on a single tobacco tissue fragment without seeming to inhibit each other's growth.

\section{Number of Flower}

Effect of PGRs on flowering of chili is shown in Fig. 1. Number of flower per plant increases with the application of PGRs up to an optimum level ( $250 \mathrm{mg} / \mathrm{l}$ of $\mathrm{GA}_{3}$ and $\mathrm{kn}$ ) in both the case of $\mathrm{GA}_{3}$ and kinetin. Treatment $\mathrm{T}_{7}(250 \mathrm{mg} / \mathrm{Kn})$ shows the highest number of flower at 30, 60 and 90 DAT. Maximum number of flower (18.0) was found in $\mathrm{T}_{7}(250 \mathrm{mg} / \mathrm{Kn})$ at 60 DAT followed by 15.5 in $\mathrm{T}_{6}(100 \mathrm{mg} / \mathrm{Kn})$ in compare with control $\left(\mathrm{T}_{0}\right)$ where the mean number of flower per plant was found 7.0. A dramatic increase in number of flower was observed when plant growth regulators applied. The result resembles the findings of Ghait et. al. (2018) in Dendranthema grandiflorium [13], Askari and Mortazaeinezhad (2016) in Rosa hybrida L. cv. "Yellow Finesse" [21].

\section{Number of Fruit}

Number of fruit is also significantly differing when plant growth regulators applied. From Table 4 it is found that better fruit setting response was found in $\mathrm{T}_{6}(100 \mathrm{mg} / \mathrm{Kn})$. In

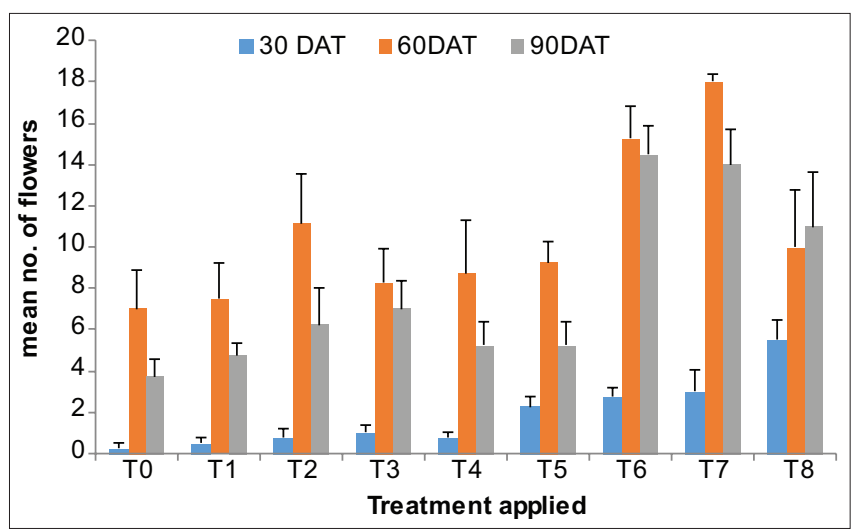

Figure 1: Effect of different plant growth regulators on number of flowers of Chili

Table 4: Effect of different plant growth regulators on number of fruit of Chili

\begin{tabular}{lcccc}
\hline Treatment & \multicolumn{4}{c}{ No. of fruit } \\
\cline { 2 - 5 } & 45 DAT & $60 \mathrm{DAT}$ & 90 DAT & Mean \\
\hline $\mathrm{T}_{0}($ Control) & $0.25 \pm 0.4$ & $5.75 \pm 3.9$ & $10.0 \pm 3.5$ & 5.3 \\
$\left.\mathrm{~T}_{1}(50 \mathrm{mg} / \mathrm{l} \mathrm{GA})_{3}\right)$ & $0.75 \pm 0.4$ & $6.75 \pm 4.6$ & $10.0 \pm 2.4$ & 5.83 \\
$\mathrm{~T}_{2}\left(100 \mathrm{mg} / \mathrm{l} \mathrm{GA}{ }_{3}\right)$ & $1.25 \pm 0.5$ & $9.75 \pm 2.4$ & $10.75 \pm 2.3$ & 7.25 \\
$\mathrm{~T}_{3}\left(250 \mathrm{mg} / \mathrm{l} \mathrm{GA}{ }_{3}\right)$ & $2.0 \pm 1.3$ & $7.25 \pm 1.7$ & $12.5 \pm 1.5$ & 7.25 \\
$\mathrm{~T}_{4}\left(350 \mathrm{mg} / \mathrm{l} \mathrm{GA}{ }_{3}\right)$ & $1.0 \pm 0.3$ & $6.0 \pm 1.4$ & $9.75 \pm 3.9$ & 5.58 \\
$\mathrm{~T}_{5}(50 \mathrm{mg} / \mathrm{l} \mathrm{Kn})$ & $1.0 \pm 0.8$ & $6.25 \pm 2.1$ & $11.5 \pm 2.4$ & 6.25 \\
$\mathrm{~T}_{6}(100 \mathrm{mg} / \mathrm{l} \mathrm{Kn})$ & $2.75 \pm 1.5$ & $10.75 \pm 2.3$ & $17.75 \pm 3.5$ & 10.42 \\
$\mathrm{~T}_{7}(250 \mathrm{mg} / \mathrm{l} \mathrm{Kn})$ & $2.0 \pm 1.4$ & $7.25 \pm 1.2$ & $12.75 \pm 2.5$ & 7.33 \\
$\mathrm{~T}_{8}(350 \mathrm{mg} / \mathrm{l} \mathrm{Kn})$ & $2.25 \pm 0.9$ & $7.25 \pm 1.4$ & $11.5 \pm 2.1$ & 7.0 \\
$\mathrm{Mean}$ & 1.47 & 7.44 & 11.82 & 6.91 \\
CV $(\%)$ & 55.32 & 22.89 & 20.86 & \\
$\mathrm{SEM}$ & 0.27 & 0.56 & 0.82 & \\
CD at $5 \%$ & 0.62 & 1.29 & 1.89 & \\
\hline
\end{tabular}


overall expression highest number was 10.42 that found in $\mathrm{T}_{6}$ (100 mg/ Kn) followed by 7.33 in $\mathrm{T}_{7}(250 \mathrm{mg} / \mathrm{Kn})$ and $7.25 \mathrm{in}$ both the $\mathrm{T}_{2}\left(100 \mathrm{mg} / \mathrm{GA}_{3}\right)$ and $\mathrm{T}_{3}\left(250 \mathrm{mg} / \mathrm{GA} \mathrm{GA}_{3}\right)$. This result go with the findings of Lou et al. (2012) in Eriobotrya japonica [22], Mukherjee and Kumar (2007) in Cajanus cajan L. [23] where they found a better fruit setting after application of kinetin.

\section{CONCLUSION}

Result of the present study suggests that the application of optimum degree of plant growth regulators $\mathrm{GA}_{3}$ and Kn improve the growth and reproduction of chili. Particularly kinetin has a great positive impact on growth and yield of chili.

\section{AUTHOR CONTRIBUTION STATEMENT}

All of the authors conceived and designed the program. Anolisa and Md. Al-Imran conducted the experiments including statistical analyses and wrote the manuscript. Subroto K. Das mainly supervised the experiments. Subroto K. Das, Riyad Hossen and A.T.M. Rafiqul Islam co-ordinate the study and gave suggestion in preparing manuscript.

\section{ACKNOWLEDGEMENTS}

The authors thank University of Barishal for providing financial and institutional support. Authors are grateful to Professor Dr. Rakha Hari Sarker and Professor Dr. M. Imdadul Hoque, University of Dhaka for their suggestions during the preparation of this manuscript and critically going through it.

\section{CONFLICT OF INTEREST}

The authors declare that they have no conflict of interest.

\section{REFERENCES}

1. Akinyosoye VO. Senior tropical agriculture for West Africa. Macmillian Education Ltd. London. 1977; 100-101.

2. Erinle ID. Present status and prospects increases production of tomatoes and pepper in Nigeria. International Symposium on Integrated Management Practices. Asian Vegetable Research and Development centre (AVRDC). 1989; 536-547.

3. Tapdiya GH, Gawande PP, Ulemale PH, Patil RK, Naware MS. Effect of Growth Regulators on Quantitative Characters of Chilli (Capsicum annuum L.).International Journal of Current Microbiology a $n \quad d$ Applied Science. 2018; Special Issue-6:2151-2157.

4. Singletary K.Red pepper: overview of potential health benefits. Nutrition Today. 2011; 46:33-47.

5. Pawar SS, Bharude NV, Sonone SS, Deshmukh RS, Raut AK, Umarkar AR.
Chilles as food, spice and medicine: a perspective. International Journal of Pharmacy and Biological Science. 2011; 1:311-318.

6. Maji AK, Banerji P. Phytochemistry and gastrointestinal benefits of the medicinal spice Capsicum annuum L. (Chilli): a review. Journa of Complementary and Integrative Medicine. 2016; 13:97-122.

7. Rylski I. Effect of night temperature on shape and size of sweet pepper (Capsicum annuum L.). Journal of the American Society for Horticultural Science. 1973; 98(2):149-152.

8. Rylski I, Halevy AH. Optimal environment for set and development of sweet pepper fruit. Acta Horticulture. 1975; 42: 55-62.

9. Erickson AN, Markhart AH. Flower production, fruit set and physiology of bell pepper during elevated temperature and vapor pressure deficit. Journal of the American Society for Horticultural Science. 2001; 126 (6): 697-702.

10. Tamilselvi C, Vijayaraghavan $\mathrm{H}$. Impact of plant growth regulators and formulations on growth of chilli (Capsicum annuum L). Journal of Plant Gene and Trait. 2014; 5:1-3.

11. Chaudhary BR, Sharma MD, Shakya SM,Gautam DM. Effect of plant growth regulators on growth, yield and quality of Chilli (Capsicum annuum L.) At rampur, chitwan. Journal of the Institute of Agriculture and Animal Science. 2006; 27:65-68

12. Shankhwar B, Nigam AK, Vasure N, Vishvakarama D. Effect of different plant growth regulators on growth of chilli (Capsicum annum L.) CV. PUSA JWALA. Agricultural update. 2017: 12(5): 1187-1189.

13. Ghait AE, Eman M, Gomaa AO, Youssef ASM, Nemr AME. Effect of kinetin and GA3 treatments on growth and flowering of Dendranthem agrandiflorium cv. Art Queen plants. Middle East Journal of Agriculture research. 2018; 7:801-815.

14. Gupta YC, Sharad K, Sharma BP, Dhiman SR, Puja S. Effect of gibberellic acid (GA3) and planting dates on growth, flowering and seed yield of China aster Callistephus chinensis (L.) Nees. Progressive Horticulture. 2015; 47(2):260-266.

15. Henschke M, Czuchaj PK, Szczepaniak SJ. The effect of benzyladenine and gibberellic acid on growth and flowering of Helleborus Orientalis Lam. Bulgarian Journal of Agricultural Science. 2015; 21(6):11981203.

16. Ibrahim SMM, Taha LS, Farahat MM. Vegetative growth and chemical constituents of croton plants as affected by foliar application of benzyladenine and gibberellic acid. Journal of American Science. 2010; 6(7):126-130

17. Seema, Khokhar M, Mukherjee D. Role of kinetin and a morphactin in leaf disc senescence of Raphanus sativus L. under low light. Physiology and Molecular Biology of Plants. 2011; 17(3):247-253.

18. Rao KUM, Mukherjee D. Some metabolic changes during development and senescence in the leaves of Cajanus cajan L. Journal of Indian Botanical Society. 1990; 69:311-314.

19. Mohamed YFY. Effect of some growth stimulants on growth flowering and postharvest quality of aster (Symphyotrichum novibelgii L.) cv. Purple Monarch. Middle East Journal of Agricultural Research. 2017; 6(2):264-273

20. Wickson M, Thimann KV. The antagonism of auxin and kinetin in apical dominance. Physiologia Plantarum. 1958; 11:62-74.

21. Askari O,Mortazaeinezhad F. Improving quality indices of Rosa 'Yellow Finesse' using methyl jasmonate and benzyl adenine. Journal of Central European Agriculture. 2016; 17(2):369-378.

22. Lou $\mathrm{H}$, Chen $\mathrm{P}$, Zheng $\mathrm{H}, \mathrm{Xu} \mathrm{C}, \mathrm{Lu} \mathrm{H}$. Effect of kinetin on quality and harvest date of loquat fruit. African Journal of Agricultural Research. 2012; 7(10): 1577-1583.

23. Mukherjee D, Kumar R. Kinetin regulates plant growth and biochemical changes during maturation and senescence of leaves, flowers, and pods of Cajanus cajan L. Biologia Plantarum. 2007; 51:80-85. 